\title{
TENDENCY OF INCIDENCE WITH NONSPECIFIC ULCERATIVE COLITIS IN KAZAKHSTAN
}

Shyryn B KENZHEBEKOVA ${ }^{1,2}$, https://orcid.org/0000-0002-4172-4887, Sauirbay B SAKHANOV ${ }^{1,2}$, https://orcid.org/0000-0002-5496-5313,

Dulat K TUREBAEV ${ }^{1}$, https://orcid.org/0000-0003-1557-3496,

Gauhar S NURTAZINOVA', https://orcid.org/0000-0001-7314-0758,

Saltanat N URAZOVA ${ }^{1}$, https://orcid.org//0000-0002-2331-1261,

Dariyana M KULMIRZAEVA ${ }^{3,2}$, https://orcid.org/0000-0001-8174-0171,

Akmaral K AMANSHAYEVA ${ }^{2}$, https://orcid.org/0000-0003-0002-5884,

Zarina A BILYALOVA², https://orcid.org/0000-0002-0066-235x,

Mirsaid N IZIMBERGENOV ${ }^{1}$, https://orcid.org/0000-0002-7234-588X,

Saken K KOZHAKHMETOV ${ }^{1,2}$, https://orcid.org/0000-0002-0075-0376,

Nurbek S IGISSINOV ${ }^{1,2,4}$, https://orcid.org/0000-0002-2517-6315

${ }^{1}$ Astana Medical University, Nur-Sultan, Republic of Kazakhstan,

${ }^{2}$ Central Asian Cancer Institute, Nur-Sultan, Republic of Kazakhstan,

${ }^{3}$ National Center of Neurosurgery, Nur-Sultan, Republic of Kazakhstan,

${ }^{4}$ Eurasian Institute for Cancer Research, Bishkek, Kyrgyz Republic

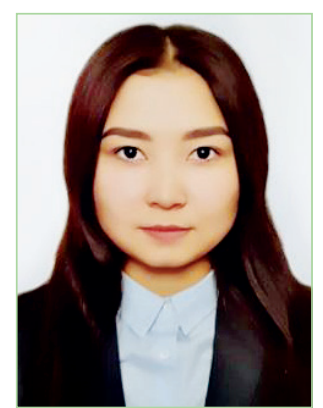

Kenzhebekova ShB
Contacts: Shyryn B

Kenzhebekova, 7 th year intern of NJSC "Astana Medical University", General Medical Practice faculty, Member of Public Association "Central Asian Cancer Institute", Nur-Sultan, e-mail: shyrynkzh07@ gmail.com

Контакты: Кенжебекова Шырын Бауыржанқызы, интерн 7 курса НАО "Медицинский университет Астана", факультет общей врачебной практики.

Член ОО "Central Asian Cancer Institute", г. Нур-Султан, e-mail: shyrynkzh07@gmail.com

Received: 22.12.2020
Nonspecific ulcerative colitis is a chronic inflammatory bowel disease of an immune nature with frequent localization in the large intestine. A pattern is noted that in the northern and western continents they suffer more often than in Asia. To identify risk factors in a population, epidemiological studies must firstly assess the incidence of disease.

Aim. To study the trends of nonspecific ulcerative colitis (NUC) incidence in Kazakhstan.

Material and methods. The research material was compiled summary reporting form number 12 of the Ministries and the Health of the Republic of Kazakhstan on new cases of nonspecific ulcerative colitis (ICD-10 - K51), established for the first time. A retrospective study was used as the main method for studying the incidence of NUC. According to generally accepted methods of biomedical statistics, extensive, intensive and equalized indicators of the incidence of NUC were calculated.

Results and discussion. For 2013-2018 14,079 new cases of NUC were registered in the republic, of which 15 were in children $-15.3 \%$, teenagers $-4.8 \%$ and adults $-79.8 \%$. The average annual incidence rate of NUC in the entire population of Kazakhstan was 13.5 $\pm 2.1 \%$ оo $(95 \% \mathrm{Cl}=9.4-17.50 / 0000)$, and for population groups having been studied was: in children $-7.2 \pm 2.1 \%$ oo $\left(95 \% \mathrm{Cl}=3.8-12.0 \%{ }_{000}\right)$, among teenagers

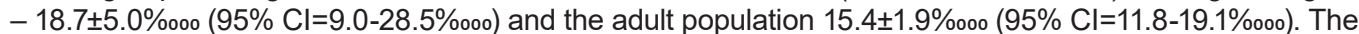
difference in morbidity between groups was statistically significant. Disease tended to decrease in all age groups: in the adult population ( $\mathrm{T}=-12.3 \%)$, children $(\mathrm{T}=-43.7 \%)$ and in adolescents $(\mathrm{T}=-50.1 \%)$.

Conclusion. According to the dynamics, NUC incidence in Kazakhstan has a decreased tendency due to the child and adolescent population. The results obtained are recommended to be taken into account by health authorities when making managerial decisions.

Keywords: nonspecific ulcerative colitis, morbidity, trends, Kazakhstan.

For reference: Kenzhebekova ShB, Sakhanov SB, Turebaev DK, Nurtazinova GS, Urazova SN, Kulmirzaeva DM, Amanshayeva AK, Bilyalova ZA, Izimbergenov MN, Kozhakhmetov SK, Igissinov NS. Tendency of incidence with nonspecific ulcerative colitis in Kazakhstan. Meditsina (Almaty) = Medicine (Almaty). 2020;11-12(221-222): 8-12. DOI: 10.31082/1728-452X-2020-221-222 -11-12-8-12

\section{т ¥ Ж Р Ы м \\ ҚАЗАҚСТАНДАҒЫ СПЕЦИФИКАЛЫК ЕМЕС ОЙЫҚ-ЖАРАЛЫ КОЛИТ АУРУШАНДЫҒЫНЫҢ ТЕНДЕНЦИЯСЫ}

Шырын Б. КЕНЖЕБЕКОВА ${ }^{1,2}$, https://orcid.org/0000-0002-4172-4887, Сәуірбай Б. САХАНОВ ${ }^{1,2}$, https://orcid.org/0000-0002-5496-5313, Дулат К. ТӨРЕБАЕВ ${ }^{1}$, https://orcid.org/0000-0003-1557-3496, Гаyhap С. НҰРТАЗИНОВА ${ }^{1}$, https://orcid.org/0000-0001-7314-0758, Салтанат Н. OPA30BA', https://orcid.org//0000-0002-2331-1261, Дарияна М. ҚҰЛМЫРЗАЕВА ${ }^{3,2}$, https://orcid.org/0000-0001-8174-0171, Ақмарал К. АМАНШАЕВА ${ }^{2}$, https://orcid.org/0000-0003-0002-5884, Зарина А. БИЛЯЛОВА², https://orcid.org/0000-0002-0066-235x, Мирсаид Н. ІЗІМБЕРГЕНОВ ${ }^{1}$, https://orcid.org/0000-0002-7234-588x, Сәкен К. ҚОЖАХМЕТОВ ${ }^{1,2}$, https://orcid.org/0000-0002-0075-0376, Нұрбек С. ИГІСІНОВ ${ }^{1,2,4}$, https://orcid.org/0000-0002-2517-6315 
${ }_{1}$ «стана медицина университеті» ҚеАҚ, Нұр-Сұлтан қ., Қазақстан Республикасы, 2Орталық Азия онкологиялық институты, Нұр-Сұлтан қ., Қазақстан Республикасы,

з «Ұлттық нейрохирургия орталығы» АК, Нұр-Сұлтан қ., Қазақстан Республикасы,

${ }^{4}$ Еуразиялық онкологиялық зерттеулер институты, Бішкек қ., Қырғызстан Республикасы

Спецификалық емес ойық-жаралы колит - иммундық сипаттағы жиі, жуан ішекте оқшауланатын, ішектің созылмалы қабынулық ауруы. Солтүстік және батыс континенттерде Азияға қарағанда жиі зардап шегетіндер байқалды. Популяциядағы қауіп фракторларын анықтау үшін эпидемиологиялық зерттеулер аурудың жиілігін бағалауы керек.

Зерттеу мақсаты. Қазақстандағы спецификалық емес ойық-жаралы колит (СЖК) ауруының даму тенденциясын зерттеу.

Материал және әдістері. Зерттеу материалы Қазақстан Республикасы Денсаулық Сақтау Министрлігінің жаңа деректері - спецификалық емес ойық-жаралы колитке (МКБ 10 - К51) қатысты № 12 жылдық форма болды. СЖК жиілігін зерттеудің негізгі әдісі ретінде ретроспективті зерттеу қолданылды. Биомедициналық статистиканың жалпы қабылданған әдістері бойынша СЖК ауруының кең, интенсивті және теңестірілген көрсеткіштері есептелді.

Нәтижелері. 2013-2018 жж. республикада 14079 жаңадан СЖК диагнозымен тіркелді, олардың ішінде: балалар - 15,3\%, жасөспірімдер - 4,8\% және ересектер - 79,8\%. Қазақстанда жалпы

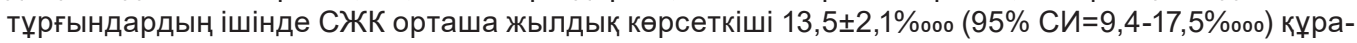

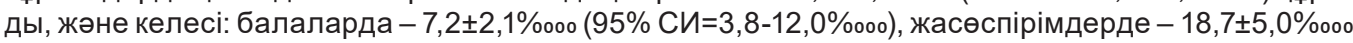

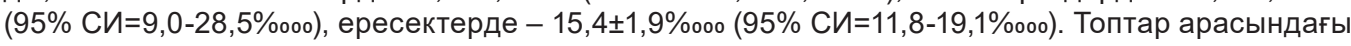
аурушаңдықтың айырмашылығы статистикалық тұрғыдан маңызды болды. Барлық жас топтарында сырқаттанушылық тенденциясының төмендеу үрдісі байқалды: ересектерде (T=-12,3\%), балаларда ( $\mathrm{T}=-43,7 \%)$ және жасөспірімдерде ( $\mathrm{T}=-50,1 \%)$.

Қорытынды. Динамикада балалар мен жасөспірімдердің есебінен жалпы Қазақстандағы спецификалық емес ойық-жаралы колит аурушаңдығының төмендеу үрдісі байқалады. Алынған нәтижелерді денсаулық сақтау органдары басқарушылық шешімдер қабылдаған кезде ескеру ұсынылады.

Негізгі сөздер: спецификалық емес ойық-жаралы колит, аурушаңдық, тенденциялар, Қазақстан.

\title{
P E 3 Ю M E
}

\section{ТЕНДЕНЦИЯ ЗАБОЛЕВАЕМОСТИ НЕСПЕЦИФИЧЕСКИМ ЯЗВЕННЫМ КОЛИТОМ В КАЗАХСТАНЕ}

\begin{abstract}
Шырын Б. КЕНЖЕБЕКОВА',2, https://orcid.org/0000-0002-4172-4887,
Сауирбай Б. САХАНОВ ${ }^{1,2}$, https://orcid.org/0000-0002-5496-5313,

Дулат К. ТОРЕБАЕВ ${ }^{1}$, https://orcid.org/0000-0003-1557-3496,

Гаухар С. НУРТАЗИНОВА', https://orcid.org/0000-0001-7314-0758,

Салтанат Н. УРАЗОВА', https://orcid.org//0000-0002-2331-1261,

Дарияна М. КУЛЬМУРЗАЕВА ${ }^{3,2}$, https://orcid.org/0000-0001-8174-0171,

Акмарал К. АМАНШАЕВА², https://orcid.org/0000-0003-0002-5884,

Зарина А. БИЛЯЛОВА ${ }^{2}$, https://orcid.org/0000-0002-0066-235x,

Мирсаид Н. ИЗИМБЕРГЕНОВ ${ }^{1}$, https://orcid.org/0000-0002-7234-588x,

Сакен К. КОЖАХМЕТОВ1,2, https://orcid.org/0000-0002-0075-0376,

Нурбек С. ИГИСИНОВ ${ }^{1,2,4}$, https://orcid.org/0000-0002-2517-6315
\end{abstract}

${ }^{1}$ HАO «Медицинский университет Астана», е. Нур-Султан, Республика Казахстан, ${ }^{2}$ Central Asian Cancer Institute, г. Нур-Султан, Республика Казахстан,

${ }^{3} \mathrm{AO}$ «Национальный центр нейрохирургии», е. Нур-Султан, Республика Казахстан,

${ }^{4}$ Eurasian Institute for Cancer Research, г. Бишкек, Республика Кырәызстан

Неспецифический язвенный колит - хроническое воспалительное заболевание кишечника, иммунного характера с частой локализацией в толстой кишке. Отмечается закономерность, что в северных и западных континентах страдают чаще, чем в Азии. Для определения факторов риска в популяции эпидемиологические исследования должны сначала оценить частоту заболевания.

Цель. Изучить тенденции заболеваемости неспецифическим язвенным колитом (НЯК) в Казахстане.

Материал и методы. Материалом исследования послужили данные сводной отчетной формы №12 Министерства здравоохранения Республики Казахстан о новых случаях НЯК (МКБ 10 - К51), установленных впервые в жизни. В качестве основного метода при изучении заболеваемости НЯК использовалось ретроспективное исследование. По общепринятым методам медико-биологической статистики вычислены экстенсивные, интенсивные и выравненные показатели заболеваемости НЯК.

Результаты и обсуждения. За 2013-2018 гг. в республике было зарегистрировано 14079 новых случаев НЯК, из них у детей - 15,3\%, подростков - 4,8\% и взрослых - 79,8\%. Среднего- 


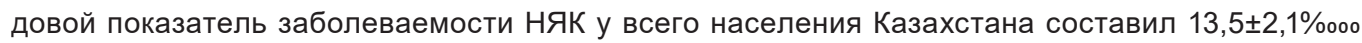
(95\% ДИ=9,4-17,5\%ооо), а у изучаемых групп населения составил: у детей $-7,2 \pm 2,1 \%$ ооо (95\%

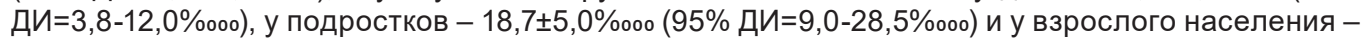
$15,4 \pm 1,9 \%$ ооо (95\% ДИ=11,8-19,1\%ооо). Различия в заболеваемости между группами были статистически значимые. Тренды заболеваемости имели тенденцию к снижению во всех возрастных группах: у взрослого населения ( $\mathrm{T}=-12,3 \%)$, у детей ( $\mathrm{T}=-43,7 \%)$ и у подростков $(\mathrm{T}=-50,1 \%)$.

Выводы. В динамике заболеваемость НЯК в Казахстане в целом имеет тенденцию к снижению за счет детского и подросткового населения. Полученные результаты рекомендуются учитывать органам здравоохранения при принятии управленческих решений.

Ключевые слова: неспецифический язвенный колит, заболеваемость, тренды, Казахстан.

Для цитирования: Кенжебекова Ш.Б., Саханов С.Б., Торебаев Д.К., Нуртазинова Г.С., Уразова С.Н., Кульмурзаева Д.М., Аманшаева А.К., Билялова З.К., Изимбергенов М.И., Кожахметов С.К., Игисинов Н.С. Тенденция заболеваемости неспецифическим язвенным колитом в Казахстане. Медицина (Алматы). 2020;11-12(221-222): 8-12. DOI: 10.31082/1728-452X-2020-221-222$11-12-8-12$

$\mathbf{N}$ onspecific ulcerative colitis is one of the difficultly diagnosed inflammatory bowel diseases and is based on diffuse ulcerative-inflammatory lesions of the colon, and often accompanied by various extra intestinal manifestations, which cause certain difficulties in its diagnosis and diagnosis in the early stages $[1,2,4,5]$. The results of epidemiological studies of NUC in the world have shown that their incidence per 100 thousand of the population is $50-230$ cases and the annual increase in patients is from 5-20 cases per 100 thousand of the population [3, 4]. At the same time, studies in the United States revealed a racial difference, as in the Caucasoid race, NUC occurs 3-5 times more often than in African Americans, while in Jews this pathology occurs in general 3.5 times more often than in others [3]. The disease occurs in all age groups, but the main increase of the incidence occurs in the working age of 20-40 years. Men and women get sick with the same frequency. Moreover, in most cases of inflammatory bowel diseases, NUC is diagnosed later from the time when first clinical symptoms appear $[4,7]$.

Aim. To study the trends of nonspecific ulcerative colitis (NUC) incidence in Kazakhstan.

\section{MATERIAL AND METHODS}

The material of the study was data from the reporting form No. 12 of the Ministry of Health of the Republic of Kazakhstan on patients with a diagnosis of Nonspecific Ulcerative Colitis (NUC) (ICD 10 - K 51), established for the first time in their life.

A retrospective study (2013-2018) with descriptive and analytical methods of modern epidemiology was used as the main method for studying the incidence of NUC. Extensive and rough indicators of morbidity are determined by the generally accepted methodology used in modern statistics. The mean value (M), the mean error $(\mathrm{m})$ and the average annual rates of increase and decrease (T, \%), 95\% confidence intervals $(95 \% \mathrm{CI})$ were calculated. The dynamics of morbidity indicators have been studied over 6 years, while trends are determined by the least squares method. The geometric mean was used to calculate the average annual growth rates and decrease in the time series. The incidence rates for children in general (up to 15 years), adolescents (15-17 years), adults (18 years and over) and the total population are calculated for 100,000 (\%ooo) of the relevant population.

\section{RESULTS AND DISCUSSION}

During the study period, in Kazakhstan there were 14,079 new cases of NUC are: children (under 15 years) $-2,160$ $(15.3 \%)$, teenagers $(15-17$ years $)-679(4.8 \%)$ and adults (18 years and older) $-11,240$ cases $(79.8 \%)$.

The average annual incidence of NUC among the entire population of Kazakhstan was $13.5 \pm 2.1 \%$ ooo $(95 \%$ CI $=9.4-$ $17.5 \%$ ooo) and in the dynamics of incidence tended to decrease from $21.7 \pm 0.4 \% 000(95 \% \mathrm{CI}=21.0-22.4 \% 000)$ in 2013 to $10.6 \pm 0.2 \% 000(95 \% \mathrm{CI}=10.1-11.1 \% 000)$ in 2018 , the difference is statistically significant $(\mathrm{t}=24.82 ; \mathrm{p}=0.000)$. The above trend remained unchanged when this indicator is had been leveled, and the average annual rate of decline was $\mathrm{T}=-17.7 \%$ (Figure 1).

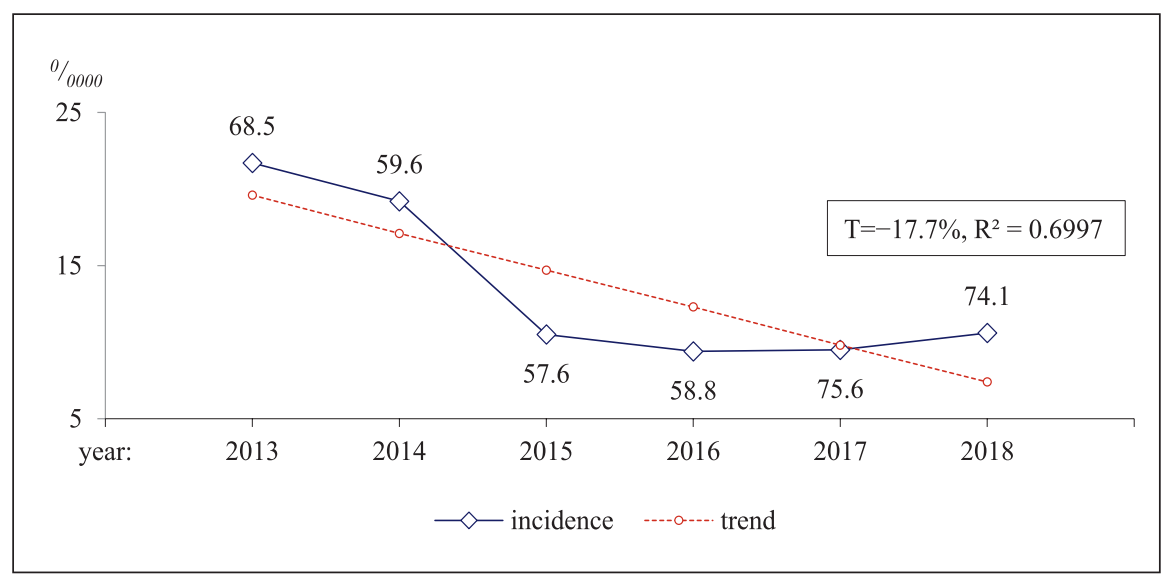

Figure 1 - Dynamics of the non-specific ulcerative colitis incidence of in the entire population of Kazakhstan for 2013-2018

The average annual incidence of NUC varied among the studied population groups. So, for children it was $7.9 \pm 2.1 \%$ (95\% CI $=3.8-12.0 \%$ ooo), for adolescents and adults it had been $18.7 \pm 5.0 \%$ 000 (95\% CI $=9.0-28.5 \%$ \%oo $)$ and $15.4 \pm 1.9 \% 000(95 \%$ $\mathrm{CI}=11.8-19.1 \%$ ooo $)$, respectively (Figure 2). 


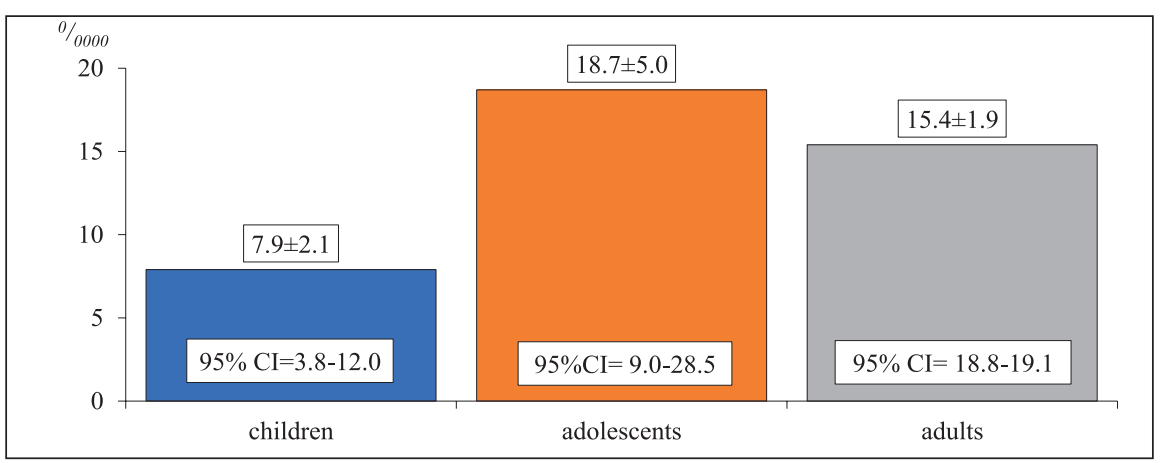

Figure 2 - Average annual incidence of NUC in the studied population groups in Kazakhstan for 2013-2018 particular worldwide concern in our century. Recently, it has been found out that there is an increase in the detection of colon cancer in patients with $\mathrm{UC}$, NUC, CD (Crohn's Disease) throughout many economically developed countries, which may be associated with an earlier onset of inflammatory bowel diseases.

To optimize effective diagnosis, treatment and dispensary observation, it is necessary to create a unified information and analytical system for monitoring and assessing this disease.
According to the graph, the incidence of NUC in the childish population of Kazakhstan decreased from $14.3 \pm 0.6 \%$ \%oo (95\% CI $=13.2-15.4 \%$ \%oo $)$ to $2.4 \pm 0.2 \%$ oо0 $(95 \% \mathrm{CI}=2.0-2.9 \%$ \%оo $)$ for the time period of 2013-2018, the changes are statistically significant $(\mathrm{t}=18.82 ; \mathrm{p}=0.000)$, and the average annual rate of decline was $\mathrm{T}=-43.7 \%$ (Figure 3).

The incidence of NUC among adolescents decreased from $42.1 \pm 2.4 \%$ (95\% CI $=37.3-46.8 \%$ ono $)$ in 2013 to $5.1 \pm 0.9 \%$ \%on (95\% CI=3.2-6.9\%000) in 2018 , also the difference is statistically significant $(\mathrm{t}=14.44 ; \mathrm{p}=0.000)$. Also, the average annual rate of decline was $\mathrm{T}=-50.1 \%$ (Figure 4 ).

In dynamics, the incidence of NUC in the republic decreased among the adult population: from $23.1 \pm 0.4 \% 000$ (95\% CI $=22.2-23.9 \%$ ooo ) in 2013 to $14.2 \pm 0.3 \%$ \%о0 (95\% CI=13.6-14.9\% $\%$ ooo) in 2018 and the difference in these years is statistically essential $(\mathrm{t}=17.80$; $\mathrm{p}=0.000)$. The average annual rate of decline was $\mathrm{T}=-12.3 \%$ (Figure 5 ).

\section{CONCLUSION}

Trends in the incidence of NUC in various studied groups of the population allowed us to assess and identify a general decreasing trend. In Kazakhstan, over the years under study, the incidence among children under 15 years old $(\mathrm{T}=-43.7 \%)$, adolescents $(15-17$ years old) $(\mathrm{T}=-50.1 \%)$ and the adult population ( $\mathrm{T}=-12.3 \%)$ tended to decrease. At the same time, in developed countries, the incidence of NUC in children and adolescents increases annually, and our results indicate, on the contrary, a sharp decrease in these groups.

The increase of morbidity rates among young employable citizens is a

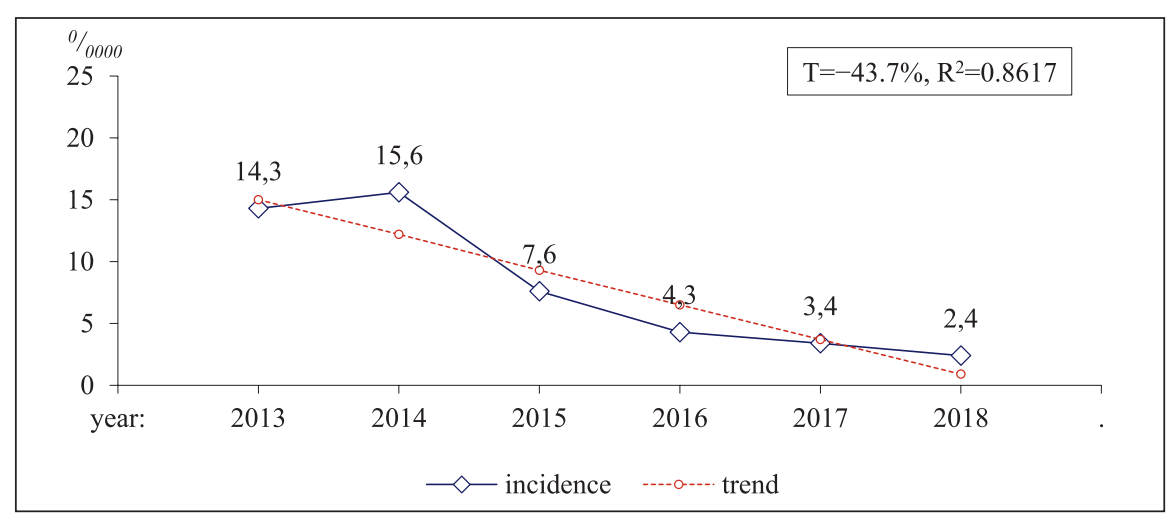

Figure 3 - Dynamics of the incidence of non-specific ulcerative colitis in the childish population of Kazakhstan for 2013-2018

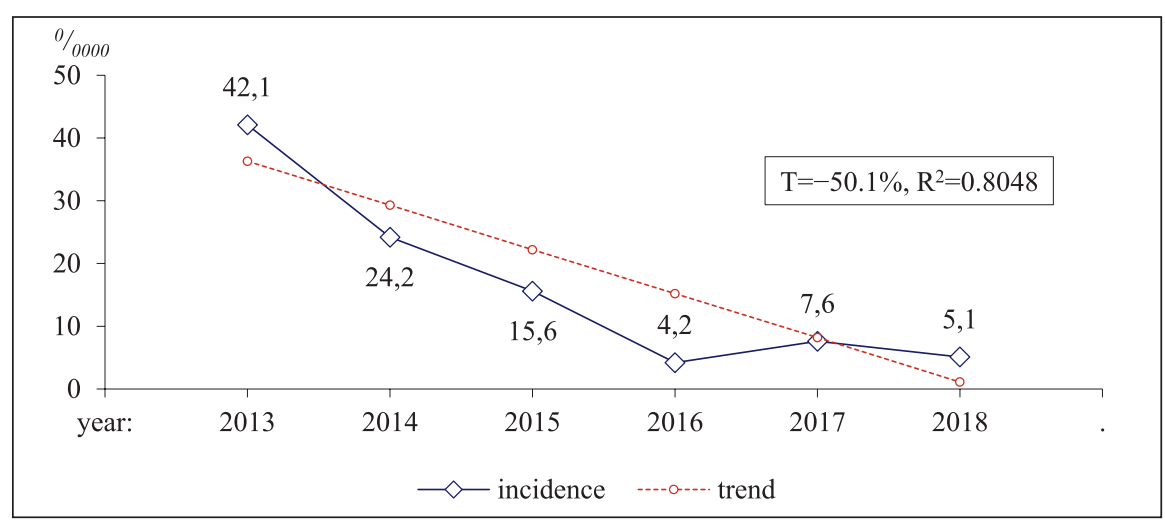

Figure 4 - Dynamics of the incidence of non-specific ulcerative colitis in the adolescent population of Kazakhstan for 2013-2018

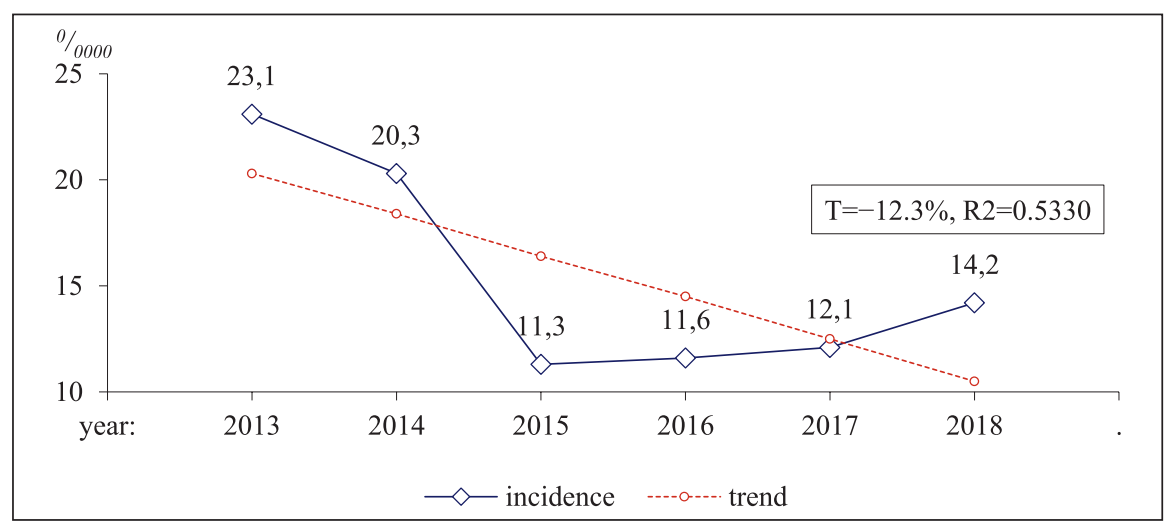

Figure 5 - Dynamics of the incidence of non-specific ulcerative colitis in the adult population of Kazakhstan for 2013-2018 


\section{Research transparency}

Research did not have a sponsorship. The authors are absolutely responsible for presenting the release script for publication.

\section{Declaration about financial and other relations}

The authors did not get the honorary for the article.

Authors' contribution:

Kenzhebekova Shyryn - data summary, primary processing of the material, writing the text of the article.

Sakhanov Sauirbay, Bilyalova Zarina - statistical processing of the material, writing the text of the article (material and methods, conclusion).

\section{REFERENCES}

1 Khalif IL, Loranskaya ID, Miklosh M. Nespetsificheskii iazvennyi kolit i bolezn Krona: klinika, diagnostika i lechenie - Vospalitelnye zabolevaniia kishechnika [Nonspecific ulcerative colitis and Crohn's disease: clinical picture, diagnosis and treatment. Inflammatory bowel disease]. Russia: Miklosh;2004:88

2 Kappelman MD, Moore KR, Allen JK, Cook SF. Recent trends in the prevalence of Crohn's disease and ulcerative colitis in a commercially insured US population. Dig Dis Sci. 2013;58(2):519-525. doi: 10.1007/s10620-012-2371-5

3 Dolgushina AI, Khusainova GM, Vasilenko AG, Kononets VA. Prevalence of inflammatory bowel disease in the Chelyabinsk Region. Almanakh klinicheskoi meditsiny = Almanakh clinical medicine . 2019.47(6):511-517 (in Russ). doi: 10.18786/2072-0505-2019-47-066

4 Sairenji T, Collins KL, Evans DV. An Update on Inflammatory Bowel Disease. Prim Care. 2017; Vol 44(4):673-692. DOI: 10.1016/j. pop.2017.07.010

5 Guan Q. A Comprehensive Review and Update on the Pathogenesis of Inflammatory Bowel Disease. Hindawi. Journal of Immunology Research. 2019. Article ID 7247238; 16 p. doi: $10.1155 / 2019 / 7247238$

6 Conrad MA, Rosh JR. Pediatric Inflammatory Bowel Disease. Pediatr Clin North Am. 2017; Vol 64(3):577-591. doi: 10.1016/j.pcl.2017. 01.005

7 Yesmagambetova E, Turebayev D, Kozhakhmetov S, Igissinov N. Incidence of nonspecific ulcerative colitis in Kazakhstan. Meditsina (Kaunas) $=$ Medicine (Kaunas). 2020;56(1):154. (In Russ.)

8 Teleuolova AS, Beysenbekova ZhA, Tayzhanova DZh, Teuesheva ZB, Guseinova ZK. Nonspecific ulcerative colitis in combination with rheumatoid arthritis (case report). Meditsinskie novosti Gruzii = Georgian Med News. 2015;(238):70-2 (In Russ.). PMID: 25693218

9 Zhang YZ, Li YY. Inflammatory bowel disease: pathogenesis. World J Gastroenterol. 2014;20(1):91-9. doi: 10.3748/wjg.v20.i1.91

10 Malik TA. Inflammatory Bowel Disease: Historical Perspective, Epidemiology, and Risk Factors. Surg Clin North Am. 2015;95(6):1105-22. doi: 10.1016/j.suc.2015.07.006

11 Nikolaus S, Schreiber S. Diagnostics of inflammatory bowel disease. Gastroenterology. 2007;133(5):1670-1689. doi: 10.1053/j. gastro.2007.09.001. PMID: 17983810

12 Rosen MJ, Dhawan A, Saeed SA. Inflammatory Bowel Disease in Children and Adolescents. JAMA Pediatr. 2015;169(11):105360. doi: 10.1001/jamapediatrics

13 Eaden J, Abrams K, Ekbom A, Jackson E, Mayberry J. Colorectal cancer prevention in ulcerative colitis: a case-control study. Aliment Pharmacol Ther. 2000;14(2):145-53. doi: 10.1046/ j.1365-2036.2000.00698.x

14 Mak WY, Zhao M, Ng SC, Burisch J. The epidemiology of inflammatory bowel disease: East meets west. $J$ Gastroenterol Hepatol. 2020; Vol 35(3):380-389. DOI: 10.1111/jgh.14872

15 Berg DR, Colombel JF, Ungaro R. The Role of Early Biologic Therapy in Inflammatory Bowel Disease. Inflamm Bowel Dis. 2019;25(12):1896-1905. doi: 10.1093/ibd/izz059
Turebaev Dulat, Kulmirzayeva Dariyana, Urazova Saltanat - writing the text of the article (introduction, conclusions).

Izimbergenov Mirsaid, Amanshayeva Akmaral, Nurtazinova Gauhar, Kozhakhmetov Saken - writing the text of the article (results), editing.

Igissinov Nurbek - concept and design of the study, approval of the final version of the article.

Conflict of interest

The authors declare no conflict of interest.

\section{СПИСОК ЛИТЕРАТУРЫ}

1 Халиф И.Л., Лоранская И.Д., Неспецифический язвенный колит и болезнь Крона: клиника, диагностика и лечение. - М.: Миклош, 2004- 88 c.

2 Kappelman MD, Moore KR, Allen JK, Cook SF. Recent trends in the prevalence of Crohn's disease and ulcerative colitis in a commercially insured US population. Dig Dis Sci. 2013;58(2):519-525. doi: $10.1007 / \mathrm{s} 10620-012-2371-5$

3 Долгушина А.И., Хусаинова Г.М., Василенко А.Г., Кононец В.А. Распространенность воспалительных заболеваний кишечника в Челябинской области // Альманах клинической медицины. 2019.47(6):511-517 (in Russ). doi: 10.18786/2072-0505-2019-47-066

4 Sairenji T, Collins KL, Evans DV. An Update on Inflammatory Bowel Disease. Prim Care. 2017; Vol 44(4):673-692. DOI: 10.1016/j. pop.2017.07.010

5 Guan Q. A Comprehensive Review and Update on the Pathogenesis of Inflammatory Bowel Disease. Hindawi. Journal of Immunology Research. 2019. Article ID 7247238; 16 p. doi: 10.1155/2019/7247238

6 Conrad MA, Rosh JR. Pediatric Inflammatory Bowel Disease. Pediatr Clin North Am. 2017; Vol 64(3):577-591. doi: 10.1016/j. pcl.2017.01.005

7 Есмагамбетова Е., Туребаев Д., Кожахметов С., Игисинов H. Заболеваемость неспецифическим язвенным колитов в Казахстане // Медицина (Каунас). 2020;56(1):154

8 Телеуова А.С., Бейсенбекова Ж.А., Тайжанова Д.Ж., Теуешева З.Б., Гусейнова З.К. Неспецифический язвенный колит в сочетании с ревматоидным артритом (клинический случай) // Медицинские новости Грузии. 2015; (238): 70-2. PMID: 25693218

9 Zhang YZ, Li YY. Inflammatory bowel disease: pathogenesis. World J Gastroenterol. 2014;20(1):91-9. doi: 10.3748/wjg.v20.i1.91

10 Malik TA. Inflammatory Bowel Disease: Historical Perspective, Epidemiology, and Risk Factors. Surg Clin North Am. 2015;95(6):1105-22. doi: 10.1016/j.suc.2015.07.006

11 Nikolaus S, Schreiber S. Diagnostics of inflammatory bowel disease. Gastroenterology. 2007;133(5):1670-1689. doi: 10.1053/j. gastro.2007.09.001. PMID: 17983810

12 Rosen MJ, Dhawan A, Saeed SA. Inflammatory Bowel Disease in Children and Adolescents. JAMA Pediatr. 2015;169(11):105360. doi: 10.1001 /jamapediatrics

13 Eaden J, Abrams K, Ekbom A, Jackson E, Mayberry J. Colorectal cancer prevention in ulcerative colitis: a case-control study. Aliment Pharmacol Ther. 2000;14(2):145-53. doi: 10.1046/j.1365-2036.2000. 00698.x

14 Mak WY, Zhao M, Ng SC, Burisch J. The epidemiology of inflammatory bowel disease: East meets west. J Gastroenterol Hepatol. 2020; Vol 35(3):380-389. DOI: 10.1111/jgh.14872

15 Berg DR, Colombel JF, Ungaro R. The Role of Early Biologic Therapy in Inflammatory Bowel Disease. Inflamm Bowel Dis. 2019;25(12):1896-1905. doi: 10.1093/ibd/izz059 